University of Rhode Island

DigitalCommons@URI

2019

\title{
Institutional and Conceptual Barriers to Climate Change Adaptation for Coastal Cultural Heritage
}

\author{
Alanna Casey \\ University of Rhode Island \\ Austin Becker \\ University of Rhode Island, abecker@uri.edu
}

Follow this and additional works at: https://digitalcommons.uri.edu/maf_facpubs

The University of Rhode Island Faculty have made this article openly available.

Please let us know how Open Access to this research benefits you.

This is a pre-publication author manuscript of the final, published article.

Terms of Use

This article is made available under the terms and conditions applicable towards Open Access

Policy Articles, as set forth in our Terms of Use.

Citation/Publisher Attribution

Casey, A., Becker, A., (2019). Institutional and Conceptual Barriers to Climate Change Adaptation for Coastal Cultural Heritage. Coastal Management, pp. 1-20. 10.1080/08920753.2019.1564952

Available at: https://doi.org/10.1080/08920753.2019.1564952

This Article is brought to you for free and open access by the Marine Affairs at DigitalCommons@URI. It has been accepted for inclusion in Marine Affairs Faculty Publications by an authorized administrator of DigitalCommons@URI. For more information, please contact digitalcommons-group@uri.edu. 
Coastal Management Journal

Word count: 6,474

\title{
Institutional and Conceptual Barriers to Climate Change Adaptation for Coastal Cultural Heritage
}

\author{
Alanna Casey ${ }^{1}$ and Austin Becker ${ }^{1}$
}

Please cite as:

CASEY, A. \& BECKER, A. 2019. Institutional and Conceptual Barriers to Climate Change Adaptation for Coastal Cultural Heritage. Coastal Management, 1-20.

Corresponding Author: Alanna Casey, Department of Marine Affairs, Kingston Coastal Institute, University of Rhode Island, Kingston, RI, 02881, USA (alannacasey@uri.edu)

${ }^{1}$ Department of Marine Affairs

University of Rhode Island

Kingston Coastal Institute

Kingston, RI 02881

USA 


\begin{abstract}
$\underline{\text { Abstract }}$
Climate change is increasing the speed at which tangible coastal cultural heritage is changing in character or being lost through weathering, erosion, and inundation (Morgan et al. 2016). Damages to coastal archaeological sites, loss of access to historical sites, and the alteration of cultural landscapes will force changes in the way researchers can study sites, tourists can enjoy places, and descendant communities who have lived in particular areas for time immemorial, and modern, local communities can utilize and relate to landscapes. In the United States, the National Park Service is a primary coastal cultural resource management organization. The National Park Service has been working on climate change adaptation for cultural resources for over a decade; however, there are few examples of parks in which long range climate change adaptation plans for cultural resources have been implemented. Building from twenty semi-structured interviews with cultural resource managers in three parks, we found that institutional structures within the National Park Service, as well as historical conceptual framings specific to the research, recreational, and interpretive values of cultural resources act as barriers to managers' ability to design and implement climate change adaptation plans. Institutional barriers managers discussed include the dependence of climate change adaptation decisions partnership projects and the leveraging of budgetary and staff resources within NPS that may affect climate change adaptation capacity. We found that park managers often saw impacts in parks that may be associated with climate change, but found it difficult to separate normal maintenance from climate change affected deterioration, which may lead to status quo management actions rather than revised planning for a changing future regime. Conceptual barriers managers discussed revealed a conflict between preservation needs of research versus interpretive uses and while NPS guidance recommends prioritization of cultural resources for preservation at the park level, regional managers were more focused on this topic than park managers. As NPS moves forward with climate change adaptation planning, opportunities to develop and improve cultural resource preservation with new technologies, improved prioritization schemes, and include public input in resource preservation may help coastal managers overcome these barriers.
\end{abstract}

Keywords: Climate Change; Climate Change Adaptation; Cultural Heritage Management; Cultural Resources; Heritage Tourism

\title{
Introduction
}

Cultural resources are the "sites, things, and practices a society regards as old, important, or worthy of conservation (Brumann 2015, 414)." Coastal communities value cultural resources for the tourist economies, sense of place, cultural or religious significance, educational facets, and the potential of these resources to contribute to research and understanding of coastal history (Green 2015; Tengberg et al. 2012; Claesson 2011). The materials, spatial contexts, and geographic arrangements of cultural sites are constantly threatened by weathering, erosion, and looting. Builders and designers constructed structures and sites for specific local climate and climate risks (WHC 2006; IPCC 2014). Coastal climate change factors including shifting species assemblages, changes in fog and wind patterns, temperature fluctuations, more intense storms and accompanying surges, sea level rise, and enhanced coastal erosion, increasingly threaten these sites (Morgan et al. 2016; Green 2015; Peter Brimblecombe 2014; Sabbioni and Bonazza 2009; Sabbioni et al. 2008; P. Brimblecombe, Grossi, and Harris 2006; Cassar 2005). The damaging impacts of climate change on cultural resources will alter the look, feel, function, and meaning of coastal landscapes. 
The National Park Service (NPS) manages the largest collection of cultural resources in the United States and provides guidance to numerous state, regional, and local preservation agencies through state historic preservation offices, the National Register of Historic Places, and other programs. NPS defines tangible cultural resources as archaeological sites, historic structures, cultural landscapes, ethnographic resources, and collections materials (NPS 2006). The Organic Act mandates that NPS preserve the natural and historic resources of the national parks "by such means as will leave them unimpaired for the enjoyment of future generations, (United States Congress 1916).” Projected climate change impacts on resources will require managers to take additional adaptive actions to protect resources since current management practices may no longer be sufficient to maintain resource condition (Colwell et al. 2012).

To determine the risk, select resources to attempt to protect and address these changing preservation needs given projected climate change impacts, management agencies with cultural resource responsibilities have started developing climate change adaptation plans. Climate change adaptation planning may take many forms. Climate change vulnerability assessments and adaptation planning processes often share the steps of identifying goals or targets to be protected, using scientific projections to estimate the impact on this goal or target resource or condition, and identifying and implementing management options to reduce the exposure or sensitivity of resources to climate change impacts or increase their ability to adapt and withstand these impacts (Rockman et al. 2016; Bierbaum et al. 2013; Sheridan and Sheridan 2013; Amberg et al. 2012; Glick, Stein, and Edelson 2011; Sabbioni, Brimblecombe, and Cassar 2010; Baron et al. 2009; Fussel 2007; Fussel and Klein 2006; Toscano 2004).

The threat of climate change to cultural heritage properties is well established in the literature (Morgan et al. 2016; Peter Brimblecombe 2014; Sabbioni, Brimblecombe, and Cassar 2010; Sabbioni et al. 2008; P. Brimblecombe, Grossi, and Harris 2006). Preservationists, cultural resource, and climate change experts have issued calls to action around the topic of climate change and cultural heritage management (Markham and Wiser 2015; Holtz et al. 2014; NPS 2010; Cassar 2005). And guidance is available for assessing resource vulnerability to climate change (Beavers, Babson, and Schupp 2016). However, as climate change adaptation planning has gotten underway, cultural resources have been underrepresented in climate change vulnerability assessments (Thompson, Staudinger, and Carter 2015) and the implementation of climate change adaptation measures, for both natural and cultural resources, has been slow (Fatoric and Seekamp 2017a; Jantarasami, Lawler, and Thomas 2010; Baron et al. 2009).

Researchers have examined barriers to climate change adaptation planning and action to determine what is stalling implementation in federal agencies including NPS (Fatoric and Seekamp 2017b; Ellenwood, Dilling, and Milford 2012; Jantarasami, Lawler, and Thomas 2010; Baron et al. 2009), as well as state agencies (Archie et al. 2012) and local governments (Amundsen, Berglund, and Westskog 2010). In land management agencies, climate change adaptation planning for natural resources may not consistently or frequently represent the top planning priority (Archie et al. 2012; Ellenwood, Dilling, and Milford 2012; Jantarasami, Lawler, and Thomas 2010). If the agency is interested in climate change adaptation planning or action, the lack of support from agency leadership, either directly, or indicated through a lack of designated funding, personnel, training, time, or incentive can serve as a barrier to action (Kemp et al. 2015; Lemieux et al. 2013; Archie et al. 2012; Amundsen, Berglund, and Westskog 2010; Jantarasami, Lawler, and Thomas 2010). And a lack of clarity on agency priorities, goals, or intended outcomes, can also bar climate adaptation action at the agency level (Jantarasami, Lawler, and Thomas 2010; Smith and Travis 2010; Baron et al. 2009). In a study specifically 
examining barriers to climate change adaptation for cultural resources, Fatorić and Seekamp (2017a) identified sixteen barriers specific to decision-making for cultural resources and climate change within the broader categories of institutional (guidance, policies and strategies), technical (historic preservation-based knowledge), and financial barriers.

Building on previous studies on barriers to climate change adaptation, this study explores barriers specific to cultural resource adaptation planning in coastal spaces and contextualizes barriers to management in the climate change adaptation process of three coastal national parks. We hypothesized that the lack of representation of cultural resources in climate change adaptation planning was caused by challenges associated with the unique uses, features, and functions of cultural resources and the policies that have historically governed the uses of these objects, sites, and places. Qualitative interviews $(n=20)$ with cultural resource managers, archaeologists, historians, historical preservationists, and interpretive staff from three NPS units in the Northeast, Southeast and Pacific-West NPS regions, revealed that the challenges managers are facing have roots in the institutional structures and conceptual frameworks that guide NPS cultural resource management. After identifying the roots of these challenges, we present opportunities for managers overcome barriers and move forward with adaptation planning for these critical resource components of coastal heritage, recreation, and research.

\section{Methods}

NPS management priorities, as well as climate change vulnerabilities, are site-specific and dependent upon the resources in each park (Smith and Travis 2010; Schroter, Polsky, and Patt 2005). Therefore, we undertook a case study approach, examining Colonial National Historical Park, Gulf Islands National Seashore, and San Francisco Maritime National Historical Park. These three sites were selected through an information-oriented process that sought maximum-variation between sites (Yin 2003; Flyvbjerg 2006). With this methodology, we sought to study cases which exemplify a varied range of coastal settings and cultural resources, not a representative sample of the diversity of coastal systems and cultural resources in the United States. Each site was selected from a pool of coastal NPS units $(n=97)$ in which the literature identified a climate change risk to the cultural landscapes, structures, or other tangible landscape features (National Park Service 2016). From coastal sites with an established climate change risk to cultural resources, we selected sites for maximum variation in coastal location, morphology, timing in the vulnerability assessment process, and the cultural resources represented at the site. Table 1 shows the selection criteria and case study sites.

\section{[Table 1]}

For a 10-month period beginning in 2016, we conducted research interviews with 20 key informants from the three National Parks and the corresponding regional offices. At each case study site, we contacted chiefs of cultural and natural resources, chiefs of interpretation, NPS park and regional staff responsible for climate change initiatives, and curatorial or historic preservation staff for interviews. Each of the key informants in the study plays a crucial role in the case study parks and corresponding regional offices in the preservation and adaptation of cultural resources to the impacts of climate change. The number of interviews was limited by the limited number of NPS staff working in each park, a concern echoed by informants during our interviews as a factor making it difficult to preserve for cultural resources. Additionally, more informants came from SAFR and the Pacific-West Region than other parks and regions because 
SAFR is a small park that works in partnership with Golden Gate National Recreation Area and as such, we included managers from this park in our interviews as these managers would be consulted in climate change decision-making at SAFR. We conducted four focus group interviews with a total of 10 informants, while the remaining informants were interviewed individually, either in person or over the phone. During focus group interviews, each participant was able to speak, disagree with their colleagues and voice concerns due to the collaborative work culture of NPS. The semi-structured interview format allowed key informants considerable leeway to broach topics they believed to be most important and encouraged informants to discuss their observations of situations that arise in their daily work.

The framework questions for the semi-structured interview were divided into three categories, as follows (see Appendix A for a complete guide to interview questions):

1. Observed changes or stability of condition of cultural resources in the park

2. Use and value of cultural resources in the park

3. Decision-making and prioritization procedures for cultural resources

When given permission ( $\mathrm{n}=19)$, we voice recorded interviews then transcribed, coded and analyzed these interviews for content and themes. Statements made during the interviews were systematically grouped, according to topic, and analyzed to determine overarching themes and patterns (Babbie 2013; Toulmin 2003; Attride-Stirling 2001; Neuman 1997). We used an open coding framework, and identified themes that arose in the transcripts, while looking for emergent frameworks within the three thematic sections of questions. Nvivo coding software expedited the data analysis process by making key words, terms, and themes easily searchable (Richards and Richards 1994). We contextualized the perspectives and ideas that arose during interviews by reviewing NPS publications, documents, and reports from produced by agency headquarters, regional offices, and case study parks (McDowell 2010).

\section{Results: Conceptual and Institutional Barriers to Cultural Resource Adaptation}

The barriers key informants identified to adapting cultural resources to climate change fell into two categories: institutional and conceptual. We define institutional barriers as challenges that result from the existing structures and frameworks within NPS. Institutional barriers include challenges in undertaking adaptation actions amidst the many other management concerns in a national park, and challenges associated with distinguishing, and therefore responding to, normal climate conditions versus climate change. We define conceptual barriers as challenges that result from qualities specific to the physical features, uses, or research requirements of the current preservation paradigm for cultural resources. Conceptual barriers include disagreement over or a lack of guidance to prioritize which resources to protect or adapt and challenges in managing the same resources for both the dual responsibilities of interpretive programs and research purposes. Table 2 shows the type of barrier, with example statements of how the barrier may appear in a coastal management context, and the role of the participant who identified this cultural resource management barrier.

[Table 2] 


\section{Institutional Barriers}

Informants discussed many barriers to climate change adaptation that stemmed from institutional factors including limited institutional support through both financial and staffing resources and policies that govern cultural resource management, organizational partnerships, and project planning. As managers discussed the situations in which they were unable to take management actions to address climate change, these challenges fell into two categories of barriers to planning: situations where climate change adaptation is beholden to or dependent on other management actions and climate change as a compounding factor in existing maintenance challenges.

\section{Institutional Barrier: Decisions are Dependent on other Management Actions}

Managers are aware of and concerned about climate change impacts on cultural resources; however, in many cases, managers identified other projects in their schedules that took priority or prevented consistent and ongoing staff time for climate change adaptation. For instance, park projects that concern historic structures but are tied to infrastructure such as the adaptive reuse of a historic building for concessions, may garner more attention, affecting the ability of staff to focus on climate adaptation projects within the park, or obligating staff capacity and financial resources on sites and structures that are not the most at risk to climate change pressures or the highest priority resources for protection based on historic significance. However, these projects may also include repairs or maintenance that help historic structures be more resilient to the impacts of climate change. Or, projects that include the park as one of many stakeholders in an effort with regional goals may also arise and affect the amount of time staff can devote to other and long-term projects, including climate change adaptation planning. Managers from both GUIS and SAFR discussed how partnership projects such as the Mississippi Coastal Improvements Project or seawall planning discussions in San Francisco may contribute in some ways to park climate change planning, but also pull staff time and focus from park climate change planning efforts.

Regional managers discussed climate change compounding ongoing challenges in managing vast expanses of park space and extensive collections of cultural resources as a question of triage across regions, siphoning resources where they are most needed to maintain as many parks as possible and gather better science to allow park managers to make decisions moving forward. While park triage represented a way for regional staff to address these compounding management challenges, park cultural resource managers were frustrated with the same budget cycles, suggesting that budget-intensive issues or occurrences such as a centennial celebration or hurricane event within the region would overwhelm budgetary resources and eliminate their chances of funding climate change projects in their park.

In addition to difficulties managers face in prioritizing staff time for climate change adaptation, the long-term nature of climate change adaptation efforts directly conflicts with existing institutional management pattern based of 5-year funding cycles. In between the time staff apply for and receive project funding, park staff my transfer to other locations, the key issues to address in the park may change, or environmental changes may enhance the speed of resource deterioration, challenging staff to implement a project that they did not design, that may no longer be a top priority, or which may no longer be adequately funded. This funding cycle presents a barrier to addressing climate change questions as quickly as they may become problematic, or to addressing the most pressing current issue rather than the most important issue 
at the time the request was written, the importance of which has since changed in nature or severity.

\section{Institutional Barrier: Climate Change is Compounding Other Maintenance or Management Challenges}

All park and regional managers identified a lack of routine maintenance as the biggest threat to cultural resources in their parks or regions, a concern echoed both in the field of historic preservation, and in coastal and environmental conservation (IPCC 2014; Haugen and Mattsson 2011; Sabbioni et al. 2008; Cassar 2005). Rightly, managers found it difficult to determine a preservation issue was related to routine weathering, climate change, or a combination of the two. Ongoing maintenance is required to maintain site conditions given weathering, visitor impacts, and vandalism, in addition to climate change. Climate change impacts may appear as incremental changes in daily maintenance tasks, such as installing dehumidifiers in the basements of historic structures or clearing boring organisms and algae from ship hulls more often. Historic preservation/curatorial staff all discussed maintenance, climate change, and changeable environments as a one-day-at-a-time issue, emphasizing the need to stay on top of maintenance.

Everyday maintenance may be part of climate change adaptation efforts. One manager at SAFR suggested, "[The Fort] is old and needs work to just keep it intact as it is. And then as sealevel rise or more frequent storms start bombarding it because it's sort of exposed out there, the maintenance that we do now will be even more important for [keeping] it intact. It's above most of the sea-level rise projections, but definitely being exposed out there and the projections of more intense storms, definitely important to fortify it as much as possible (Personal Communication 2016)." However, if managers address problems that are both persistent and increasing in intensity with short-term fixes, these management actions may be ineffective or may result in staff and financial resources being applied to stop-gap measures rather than a longer-term preservation strategy.

Despite the climatic differences between Florida, California, and Virginia, managers from each region discussed the challenges associated with preserving historic resources in the coastal environment, citing salt, fog, and coastal erosion as long-understood threats to the resources. "If you've got fortifications on the seacoast, it's just, you know, Mother Nature (Personal Communication 2016)." Managers at GUIS also cited vandalism by visitors as part of the ongoing maintenance challenge. As climate change compounds these existing management challenges, the increasing intensity, timeframe, and uncertainty of potential impacts on cultural resources will require institutional changes to resource management protocols.

\section{Conceptual Barriers}

In addition to challenges posed by existing policies and programs in leveraging management time, technical, and financial resources to address climate change adaptation, informants expressed challenges stemming from how managers use cultural resources. These challenges include determining what information can contribute to prioritization and addressing conflicting park management goals that may be siloed between different employees or organizational divisions. As managers discussed the situations in which they were unable to take management actions to address climate change, these various challenges fell into two categories of barriers caused by conceptual features of cultural resources: intentional prioritization of which 
resources to protect is largely unprecedented and research and interpretive uses of the same resource require different management actions.

\section{Conceptual Barrier: Prioritization of which Resources to Protect is Largely Unprecedented}

NPS staff are being faced with deciding which cultural resources to prioritize for protection through adaptive measures, and which resources to allow to be altered, submerged, or destroyed by climate change factors. Currently, managers protect cultural resources as dictated by NPS and park legislation. At each location, managers were unanimously worried about the coastal artifacts outlined in park enabling legislation, citing both location and material type as key factors in site vulnerability to climate change. Managers in San Francisco expressed the greatest concern over large metal armament, accompanying coastal fortifications and bunkers. GUIS managers also expressed concern about metal artifacts, as well as coastal military fortifications, citing the movement of sand in barrier island systems as an ongoing threat to the resources. Managers at COLO believed buried archaeological deposits to be the most vulnerable resources in their park, citing ongoing coastal erosion, sea level rise, and salt water intrusion as important considerations. Each of the resource types of greatest concern to managers aligned closely with park preservation legislation specifying which cultural resources the park interprets and protects. In addition, informants said National Historic Landmarks (NHLs) receive the most attention and are maintained to the highest standard and were frequently cited as sites of high concern for climate change impacts.

However, within the categories of resources for which managers expressed concern, they did not agree on how to prioritize these resources for protection or the goals for protection. NPS guidance recommends a case-by-case consideration of the differing significance and context of unique cultural resources situated in diverse natural park settings when assessing climate change alternatives. The variation in prioritization methods discussed by participants indicates that NPS employees are not in agreement as to whether the condition or integrity of the resource, significance of the resource to the historical record, or the importance of the resource for current visitors to the park should inform which cultural resources are the focus of preservation efforts. Adaptation staff interviewed believed priority should go to sites that are considered most vulnerable to climate change, while some historic preservation and curatorial staff believed priority should go to sites that are in better condition and have a better chance of withstanding climate hazards, even though these sites may not be as vulnerable to sea level rise or increasing coastal erosion. Interpretation and historic preservation/curatorial staff discussed visitor safety and access as critical components in any park prioritization, management, and maintenance procedure. Cultural resource managers were more likely to discuss significance, purpose, and enabling legislation when thinking about prioritization of cultural resources for preservation in the face of climate change. Finally, when asked about whether especially rare sites would receive priority consideration for climate change impacts, informant's responses were mixed. Many informants indicated that rare sites would rise to the top through competitive funding reviews. However, outside of this review process, and existing designation procedures such as NHLs, there is not currently a system to prioritize rare sites or check for regional or national site diversity.

While cultural resource managers at the park and regional level discussed many different values that can influence preservation and prioritization decisions, partner organizations and the public may also contribute to cultural resource prioritization. Informants in the Pacific-West Region found public input through a climate change public process helpful as they begin to think 
about climate change adaptation. However, informants in the Southeast Region suggested that the public interest may be particularly focused on certain resources, suggesting that lighthouses, forts, and Civil War sites have contingencies of public support, thus leaving other resources such as prehistoric buried archaeological sites, more exposed to damages.

\section{Conceptual Barrier: Research and Interpretive Uses Require Different Management Actions}

Coastal cultural resources are used both for academic research and for the enjoyment and education of park visitors. Academic research requires the maintenance of the site context and artifacts; however, interpretation staff frequently tell the history of place without corresponding physical artifacts to show visitors. All but one informant indicated that park visitors accept the interpretation of sites without the presence or display of physical artifacts or structures. Because sites can be interpreted repeatedly without the presence of physical artifacts, or sometimes even the presence of the original boundaries of the site, without decreasing the availability to future visitors, the interpretation of sites is a renewable resource use. Because park mission statements establish visitor experience, education, and research as park objectives, these different uses of the park may offer different climate change adaptation alternatives.

Cultural resource staff and interpretation staff alike discussed the adaptive reuse of historic structures as a win-win for parks. Through adaptive reuse, cultural resources are preserved and prioritized for maintenance given their new use for interpretive activities. Historic preservation/curatorial staff discussed the conflict between interpretive and research uses in terms of visitor safety and accessibility, outlining the balance between preserving the integrity of historic sites and structures, while making sure that as many sites as possible are open to park visitors. Preserving the traditions associated with cultural landscapes has a different set of requirements than preserving archaeological sites or historic structures. The conceptual barriers to climate change adaptation action caused by this conflict in resource needs present opportunities for additional preservation strategies outside of site excavation or shoreline armoring.

\section{Disciplinary Focus and Barriers to Cultural Resource Climate Change Adaptation}

NPS interpretation, cultural and natural resource management, curatorial and historic preservation, and climate adaptation staff are leading and joining conversations on climate change adaptation happening at park, regional, and national levels in capacities consistent with their experience and expertise. Managers from each disciplinary perspective were included in this study because of their involvement in the cultural resource and climate change conversation within NPS. Adaptation staff, who focus on coordinating and providing scientific information for climate change adaptation efforts, in this study were very aware of conversations on prioritization of resources, but were less likely to discuss the management decisions within the park that may supersede adaptation decision-making. Similarly, Interpretation staff who participated in this study were very engaged in the different management requirements for research versus interpretive uses of sites, but less likely to discuss prioritization and compounding maintenance and management issues. The two tables below show the percentage of staff who discussed each barrier by discipline and the number of mentions of each barrier.

[Table 3]

[Table 4] 


\section{Cultural Resource Management at the Park and Regional Levels}

National parks are managed by in-park staff who are supported by regional subject matter experts who assist in designing, conducting, or implementing scientific studies that assist park managers in decision-making and provide other assistance as needed. Regional staff may support park staff and collaborate to seek project funding, including for cultural resource climate change adaptation initiatives, and provide parks with management guidance and best practices on topics including managing cultural resources for climate change. For this study, we interviewed eight regional staff members, each of whom are focused on cultural resource preservation and/or climate change adaptation at parks including GUIS, COLO, and SAFR.

Comparing the responses of regional and park staff, park staff were more likely to discuss other management decisions creating barriers to undertaking climate change action (100\% park staff versus 50\% regional staff) and the challenges in balancing research and interpretive uses of cultural resources (100\% park staff versus $75 \%$ regional staff) while regional staff were more likely to discuss challenges associated with prioritizing cultural resources for preservation (75\% park staff versus $100 \%$ regional staff). Other management challenges that divert staff time and resources from addressing climate change, as well as the balance of research and interpretive uses are challenges that park managers address frequently and can be discussed on a resource-byresource basis, at the park level. Regional managers were more likely to discuss resource prioritization. While managers discussed that funding mechanisms The NPS Cultural Resource Climate Change Strategy published in 2016 recommends considering the unique values associated with cultural resources in different sites and with diverse meanings and significances to different facets of North American history (Rockman et al. 2016). This discrepancy between the number of NPS staff thinking about prioritization at the regional level versus the smaller number at the park level is an opportunity for NPS to think regionally and nationally about preservation of cultural resources that represent a diverse American history, seeking information from park staff on preservation needs, requirements, and other factors such as safety, access, and visitation, and involving cultural resource partners and the public in prioritization decisionmaking.

\section{Adaptation Opportunities for Cultural Resources}

In addition to barriers, discussions with key informants highlighted potential opportunities for overcoming these barriers. As cultural resource management organizations develop methods for climate change adaptation for resources, opportunities to document actions, as well as changes to rethink best practices may enhance management moving forward. Some key informants suggested input from the public was helpful in the prioritization of action and preservation in the adaptation process. This coordination with the community to help inform priorities may also represent an opportunity to update the preservation priorities of the park to be more representative of the priorities of a diverse and modern public. The lack of established prioritization methods could allow for increased public input or community consultation during the prioritization process. Preservation has always necessitated choices. Sites and structures have been lost due to development and other pressures, but climate change affords an opportunity to explain the reasons for priority setting and contemporary thought behind preserving one site over another.

Preservation of historic structures aims for the representation of a certain moment in time. However, many informants discussed the inherent contradiction between the preservation of a moment in time when the historic use of a site would have included dynamic updates to bolster 
the site against climatic conditions. However, these past historic adaptations could be reconsidered for their historic authenticity. Recent publications by NPS, starting with Revisiting Leopold and Memorandum 14-02 in 2014 and established further with Directors Order 100 in 2016 each recognize that cultural resources will be confronted with climatic as well as social and cultural shifts, and may require interference to maintain their condition (Jarvis 2016; Colwell et al. 2014; Jarvis 2014). In 2016, the Cultural Resources Climate Change Response Strategy was published to help interpret and guide the application of Memorandum 14-02 (Rockman et al. 2016). While these documents encourage changes in management perception and policy, the Secretary's standards on historic preservation that govern day-to-day maintenance, as well as the National Historic Preservation Act and National Environmental Policy Act have yet to be updated. The new management paradigm represented by these documents presents an opportunity to update historic preservation guidelines to include ongoing climate maintenance as an authentic, integral feature of site preservation. This may allow sites to adapt to climate change while retaining their integrity.

All but one informant in this study believed that the interpretation of cultural heritage sites for visitors could continue without the tangible presence of cultural artifacts. While the ability to maintain the interpretive functionality of a site, without the presence of corresponding artifacts is a commonly used tool for NPS interpretation staff, this strategy is not an explicit consideration in the prioritization of site protection and adaptation given climate change. If these objects are not required for interpretation and site education, prioritization of cultural resources in the face of climate change may instead focus on the research potential of sites, structures, and artifacts. Focusing on the research potential presents challenges because it is difficult to determine which sites will be important in the future. NPS guidance documents include losing resources and interpreting this loss as an option and the explicit consideration of this possibility in climate adaptation planning may assist parks in long-term strategizing and goal-setting for cultural resource preservation and interpretation. Additionally, improving and developing technologies may provide better opportunities for preserving images, dimensions, and spatial information from sites that cannot be researched or recovered before they are lost to climate change, either due to a lack of time, financial resources, or staff capacity. Table 5 summarizes the barriers and corresponding opportunities as integrated climate change adaptation planning progresses.

\section{[Table 5]}

\section{Discussion: Understanding and Overcoming Barriers in Cultural Resource Adaptation}

As coastal managers begin to plan for and undertake climate change adaptation actions, institutional management structures that focus on daily rather than long-term maintenance and prioritize dual-use or other specific projects may create barriers to effective climate change adaptation action. Conceptual barriers stem from the complexity of prioritizing cultural resources for preservation with little historic precedent, as well as changing patterns of which histories within complex and overlapping coastal landscapes are of interests to locals and visitors that may prescribe different uses of the landscape. Climate change represents an unprecedented challenge for management agencies and institutions. Historical institutional structures and conceptual understandings and goals of management need to be examined to determine how these structures and ideas are creating barriers to coastal climate change adaptation (Adamson, Hannaford, and Rohland 2018). The remainder of this section will address this question and present opportunities 
for managers to overcome barriers to climate change adaptation planning and action for cultural resources.

\section{Guidance for Resource Prioritization}

Difficulties in prioritizing resources were a top concern for key informants from all three case studies. Prioritization requires managers to select which resources will be protected from climate change, and which ones will not. Managers have historically faced decisions about which resources to research, preserve, or display as heritage (Ashworth 2013; Lowenthal 1996). However, because climate change impacts are predicted, this form of slow disaster provides an opportunity to plan for wide-scale impacts, allowing managers and stakeholders to strategize their adaptation actions. NPS defines resource priority as a combination of vulnerability and significance (Rockman et al. 2016). Resource significance can be defined by listing or potential listing on the National Register of Historic Places, or through factors such as research potential, visitor use and access, or adaptive reuse potential. In addition to the challenge of determining present resource significance, the meaning of different cultural sites and landscapes changes relative to the time-period and audience. Recently, NPS has expanded to include urban, industrial sites that may not have been considered important just decades ago. The sites and structures that are selected for preservation, interpretation, and presentation were selected through a political process, and are not necessarily representative of the diversity of the past (Lowenthal 2015; de Groot 2009). Climate change and associated decision-making will add another layer of political complexity to the preservation of cultural heritage. Sites omitted from park legislation in the past may require special consideration to work towards a collection of American cultural heritage that is as representative as possible of modern ideas of a diverse American history.

In addition to association with important people or events in the past, the condition of the resource, or resource integrity, contributes to whether it is considered significant using National Register criteria. Resources that have begun slowly eroding or experiencing damage that may be exacerbated by climate change may be at a disadvantage for significance assessment. Existing institutional requirements for resource condition need to be reconsidered given climate change realities. In NPS, Gateway National Recreation Area prioritized each of its park resources starting before and continuing after Hurricane Sandy as part of their General Management Plan update (Mahan 2015; NPS 2014). The process that Gateway National Recreation Area conducted to prioritize cultural resources was specific to the resources of that location; however, other parks may find lessons in the challenges and outcomes of this process.

\section{Balancing Renewable and Non-Renewable Uses}

Cultural resources have three unique management requirements: first, some cultural resources require maintenance or interference to persist in a stable condition. Second, cultural resources may be constructed and degraded at a faster time scale than some natural features. Third, quantitative means of preservation (i.e., preserving at least a set number of acres or a specific number of representative sites) may not be valid for unique cultural resources. These challenges are compounded by the fact that cultural resources may include living resources such as key plant species and have both renewable and non-renewable uses. Archaeological sites are irreplaceable; however, the living features that contribute to cultural landscapes and ethnographic resources are renewable (Beavers, Babson, and Schupp 2016). While the materials and spatial context that form an archaeological site are non-renewable, the history of the area, as informed by archaeological and historical research can be told to visitors repeatedly, without additional 
resource inputs. However, the loss of the non-renewable qualities of the resources may limit future research, which can clarify, improve, or correct past academic understandings.

DOI preservation requirements for historic structures may not allow for continuous replacement of certain features due to weather conditions or certain modernizations for changing weather patterns or combinations (Grimmer 2017). Manmade sites and structures were once dynamic places that were updated as needs changed (Guerrini and Dugan 2010). Once these sites become historic structures, they are preserved in a more static situation. Many informants in this study discussed a conflict between the updates to sites and structures in the past and the preservation practices of today. Because sites and structures are now used to display past conditions, the adherence to past building materials is of greater importance. NPS is actively working to develop guidance for the assessment of both natural and cultural systems in the face of climate change and has put forward a series of documents to that end (Beavers, Babson, and Schupp 2016; Jarvis 2016; Morgan et al. 2016; Rockman et al. 2016; Jarvis 2014). However, because many climate change adaptation procedures start by identifying, rather than questioning, the preservation goals of the park, given climate change projections, managers may not be able or encouraged to rethink whether more adaptive historic preservation standards, in terms of material, condition, and appearance, could free staff capacity and financial resources to focus on more vulnerable coastal cultural resources, such as archaeological sites, which may not be able to be protected with more adaptive construction measures.

\section{Conclusion: Next Steps for Cultural Resources and Climate Change Adaptation}

The institutional and conceptual barriers identified in this study hinder efforts to develop and implement climate change adaptation plans to protect coastal cultural heritage. Understanding these barriers can help managers overcome these challenges before undertaking vulnerability assessment, prioritization, or adaptation planning processes. Cultural resource managers, historic preservation/curatorial staff, interpretation staff, and adaptation coordinators at the park and regional level must work together to preserve the sites and artifacts that represent and evidence American history. They will need to thoughtfully prioritize climate change adaptation within other management actions, budgetary plans, and staffing capacity. Understanding these barriers may also raise awareness that management plans that address ongoing challenges need to adjust to include changing and potentially increasing maintenance and repair needs alongside plans for changing park landscapes. Policies that reduce the adaptability of budgets, staff time, and historic preservation regulations need to be reconsidered for climate change realities. And as national and regional managers provide guidance on prioritization of cultural resources within parks, these conceptual barriers suggest that managers at the park level will need to engage with resource prioritization mechanisms and managers may be able to take advantage of public input and new technologies that may preserve the research potential of archaeological sites, even without the presence of artifacts, could contribute to cultural heritage preservation in the face of coastal climate change. 


\section{References Cited}

Adamson, G.C.D., M.J. Hannaford, and E. Rohland. 2018. "Re-Thinking the Present: The Role of a Historical Focus in Climate Change Adaptation Research." Global Environmental Change 48: 195-205.

Amberg, S., K. Kilkus, S. Gardener, J.E. Gross, M. Wood, and B. Drazkowski. 2012. "Badlands National Park: Climate Change Vulnerability Assessment." Natural Resource Report NPS/BADL/NRR--2012/505. Fort Collins, Colorado: National Park Service.

Amundsen, H., F. Berglund, and H. Westskog. 2010. "Overcoming Barriers to Climate Change Adaptation--A Question of Multi-Level Governance?" Environment and Planning C: Government and Policy 28: 276-89. https://doi.org/10.1068/c0941.

Archie, K.M., L. Dilling, J.B. Milford, and F.C. Pampel. 2012. "Climate Change and Western Public Lands: A Survey of U.S. Federal Land Managers on the Status of Adaptation Efforts." Ecology and Society 17 (4): 20. https://doi.org/10.5751/ES-05187-170420.

Ashworth, G. 2013. "From History to Heritage-From Heritage to Identity: In Search of Concepts and Models." In Building a New Heritage: Tourism, Culture and Identity in the New Europe, 13-30. New York, New York: Routeledge.

Attride-Stirling, J. 2001. "Thematic Networks: An Analytical Tool for Qualitative Research." Qualitative Research 1 (3): 385-405.

Babbie, E. 2013. The Practice of Social Research. 13th ed. Belmont, California: Wadsworth Cengage Learning.

Baron, J.S., L. Gunderson, C.D. Allen, E. Fleishman, D. McKenzie, L.A. Meyerson, J. Oropeza, and N. Stephenson. 2009. "Options for National Parks and Reserves for Adapting to Climate Change.” Environmental Management 44 (December): 1033.

Beavers, R.L., A.L. Babson, and C.A. Schupp. 2016. "Coastal Adaptation Strategies Handbook." NPS 999/134090. Washington, D.C.: National Park Service.

Bierbaum, R., J.B. Smith, A. Lee, M. Blair, L. Carter, S. Chapin III, P. Fleming. 2013. “A Comprehensive Review of Climate Adaptation in the United States: More than before, but Less than Needed." Mitigation and Adaptation Strategies for Global Change 18 (3): 361-406.

Brimblecombe, P., C.M. Grossi, and I. Harris. 2006. "Climate Change Critical to Cultural Heritage.” In Proceedings of the International Conference on Heritage, Weather and Conservation. Madrid, Spain: Taylor and Francis.

Brimblecombe, P. 2014. "Refining Climate Change Threats to Heritage." Journal of the Institute of Conservation 37 (2): 85-93. https://doi.org/10.1080/19455224.2014.916226.

Brumann, C. 2015. “Cultural Heritage.” International Encyclopedia of the Social \& Behavioral Sciences. Amsterdam, Netherlands: Elsevier.

Cassar, M. 2005. "Climate Change and the Historic Environment." London: Center for Sustainable Heritage, University College London. http://discovery.ucl.ac.uk/2082/1/2082.pdf.

Claesson, S. 2011. "The Value and Valuation of Maritime Cultural Heritage." International Journal of Cultural Property 18: 61-80.

Colwell, R., S. Avery, J. Berger, G.E. Davis, H. Hamilton, T. Lovejoy, S. Malcom, A. McMullen, M. Novacek, R. Roberts, R. Tapia, and G. Machlis. 2014. "Revisiting Leopold: Resource Stewardship in the National Parks." Parks 20 (2): 15-24.

Eisenack, K., S.C. Moser, E. Hoffmann, R.J.T. Klein, C. Oberlack, A. Pechan, M. Rotter, and C.J.A.M. Termeer. 2014. "Explaining and Overcoming Barriers to Climate Change 
Adaptation." Nature Climate Change, September.

https://doi.org/10.1038/NCLIMATE2350.

Ellenwood, M.S., L. Dilling, and J.B. Milford. 2012. "Managing United States Public Lands in Response to Climate Change: A View from the Ground Up." Environmental Management 49: 954-67.

Fatoric, S., and E. Seekamp. 2017a. "Are Cultural Heritage and Resources Threatened by Climate Change? A Systematic Literature Review.” Climatic Change 142 (1): 227-54. . 2017b. "Securing the Future of Cultural Heritage by Identifying Barriers to and Strategizing Solutions for Preservation Under Changing Climate Conditions." Sustainability 9: 21-43.

Flyvbjerg, B. 2006. "Five Misunderstandings About Case-Study Research.” Qualitative Inquiry 12 (2): 219-45. https://doi.org/10.1177/1077800405284363.

Fussel, H.M. 2007. "Adaptation Planning for Climate Change: Concepts, Assessment Approaches, and Key Lessons." Sustainability Science 2: 265-75.

Fussel, H.M., and J.T. Klein. 2006. "Climate Change Vulnerability Assessments: An Evolution of Conceptual Thinking." Climatic Change 75: 301-29.

Glick, P., B.A. Stein, and N.A. Edelson. 2011. Scanning the Conservation Horizon: A Guide for Climate Change Vulnerability Assessment. Washington, D.C.: National Wildlife Federation.

Green, T.J. 2015. "Cultural Resource Management: Conservation of Cultural Heritage." International Encyclopedia of the Social \& Behavioral Sciences. Amsterdam, Netherlands: Elsevier.

Grimmer, A.E. 2017. "The Secretary of the Interior's Standards for the Treatment of Historic Properties with Guidelines for Preserving, Rehabilitating, Restoring \& Reconstructing Historic Buildings.” U.S. Department of the Interior. https://www.nps.gov/tps/standards/treatment-guidelines-2017.pdf.

deGroot, J. 2009. Consuming Heritage: Historians and Heritage in Contemporary Popular Culture. New York City, New York: Routledge.

Guerrini, A., and J.E. Dugan. 2010. "Informing Ecological Restoration in a Coastal Context." In Restoration and History: The Search for a Usable Environmental Past, 131-42. New York City, New York: Routledge.

Haugen, A., and J. Mattsson. 2011. "Preparations for Climate Change's Influences on Cultural Heritage." International Journal of Climate Change Strategies and Management 3 (4): 386-401.

Holtz, D., A. Markham, K. Cell, and B. Ekwurzel. 2014. "National Landmarks at Risk: How Rising Seas, Floods, and Wildfires Are Threatening the United States' Most Cherished Historical Sites." Union of Concerned Scientists. http://www.ucsusa.org/sites/default/files/legacy/assets/documents/global_warming/Natio nal-Landmarks-at-Risk-Full-Report.pdf.

IPCC. 2014. "Climate Change 2014: Impacts, Adaptation and Vulnerability." Contribution of Working Group II to the Fifth Assessment Report of the Intergovernmental Panel on Climate Change. Part A: Global and Sectoral Aspects. New York City, New York: Cambridge University Press.

Jantarasami, L.C., J.J. Lawler, and C.W. Thomas. 2010. "Institutional Barriers to Climate Change Adaptation in U.S. National Parks and Forests." Ecology and Society 15 (4): 33. 
Jarvis, J. 2014. "Policy Memorandum 14-02: Climate Change and Stewardship of Cultural Resources." National Park Service. https://www.nps.gov/preservationplanning/downloads/Director_Memo_onClimateChange_and_Stewardship_of_CulturalR esources.pdf

- 2016. "Director's Order \#100: Resource Stewardship for the 21st Century." https://www.nps.gov/policy/dorders/do_100.htm

Kemp, K.B., J.J. Blades, P.Z. Klos, T.E. Hall, J.E. Force, P. Morgan, and W.T. Tinkham. 2015. "Managing for Climate Change on Federal Lands of the Western United States: Perceived Usefulness of Climate Science, Effectiveness of Adaptation Strategies, and Barriers to Implementation." Ecology and Society 20 (2): 17-.

Lemieux, C.J., J.L. Thompson, J. Dawson, and R.M. Schuster. 2013. "Natural Resource Manager Perceptions of Agency Performance on Climate Change." Journal of Environmental Management 114 (15): 178-89.

Lowenthal, D. 1996. Possessed by the Past: The Heritage Crusade and the Spoils of History. New York City, New York: The Free Press.

- 2015. The Past Is a Foreign Country-Revisited. Cambridge: Cambridge University Press.

Mahan, H. 2015. "Fulfilling the Promise of 'Parks to People' in a Changing Environment: The Gateway National Recreation Area Experience." The George Wright Forum 32 (1): 5158.

Markham, A., and J. Wiser. 2015. “A Heritage Coalition's 'Call to Action' on Climate Change and Cultural Heritage." Forum Journal 29 (4): 19-23.

McDowell, L. 2010. "Interviewing: Fear and Liking in the Field." In The Sage Handbook of Qualitative Geography, 156-71. Thousand Oaks, California: Sage Publications.

Morgan, M., M. Rockman, C. Smith, and A. Meadow. 2016. "Climate Change Impacts on Cultural Resources." Washington, D.C.: National Park Service Cultural Resources Partnerships and Science.

Moser, S.C., and J.A. Ekstrom. 2010. "Barriers to Climate Change Adaptation: A Diagnostic Framework." Proceedings of the National Academy of Sciences 107 (51): 22026-31.

National Park Service. 2014. "A New Vision for a Great Urban National Park: Gateway National Recreation Area Final General Management Plan Environmental Impact Statement."

- 2016. "NPS Deferred Maintenance Reports." https://www.nps.gov/subjects/plandesignconstruct/defermain.htm.

NPS. 2006. Management Policies. Washington, D.C.: U.S. Government Printing Office.

- 2010. "A Call to Action: Preparing for a Second Century of Stewardship and Engagement." Fort Collins, Colorado: National Park Service. http://www.nps.gov/calltoaction/PDF/ Directors_Call_to_Action_Report.pdf.

Neuman, W.L. 1997. Social Research Methods: Qualitative and Quantitative Approaches. Boston, Massachusetts: Allyn and Bacon.

Richards, T.J., and L. Richards. 1994. "Using Computers in Qualitative Research.” In Handbook of Qualitative Research, 445-62. Thousand Oaks, California: Sage Publications.

Rockman, M., M. Morgan, S. Ziaja, G. Hambrecht, and A. Meadow. 2016. "Cultural Resources Climate Change Strategy.” Washington, D.C.: Cultural Resources, Partnerships, and Science and Climate Change Response Program, National Park Service. 
Sabbioni, C., and A. Bonazza. 2009. "How Mapping Climate Change for Cultural Heritage? The Noah's Ark Project.” In Climate Change and Cultural Heritage, 37-41. Bari, Italy: Edipuglia.

Sabbioni, C., P. Brimblecombe, and M. Cassar, eds. 2010. The Atlas of Climate Change Impacts on European Cultural Heritage: Scientific Analysis and Management Strategies. New York City, New York: Anthem Press.

Sabbioni, C., M. Cassar, P. Brimblecombe, and R.A. Lefevre. 2008. "Vulnerability of Cultural Heritage to Climate Change." European and Mediterranean Major Hazards Agreement. Strasbourg, France: Council of Europe.

Schroter, D., C. Polsky, and A.G. Patt. 2005. "Assessing Vulnerabilities to the Effects of Global Change: An Eight Step Approach.” Mitigation and Adaptation Strategies for Global Change 10: 573-96.

Sheridan, R., and J. Sheridan. 2013. International Heritage Instruments and Climate Change. Champaign, Illinois: Common Ground Publishing, LLC.

Smith, J.B., and W.R. Travis. 2010. "Adaptations to Climate Change in Public Lands Management." Resources for the Future Issue Brief 10 (4): 1-16.

Tengberg, A., S. Fredholm, I. Eliasson, I. Knez, K. Saltzman, and O. Wetterberg. 2012. "Cultural Ecosystem Services Provided by Landscapes: Assessment of Heritage Values and Identity." Ecosystem Services 2: 14-26.

Thompson, L.M., M.D. Staudinger, and S.L. Carter. 2015. "Summarizing Components of U.S. Department of the Interior Vulnerability Assessments to Focus Climate Adaptation and Planning." 2015-1110. Reston, Virginia: U.S. Department of the Interior and U.S. Geological Survey.

Toscano, M.A. 2004. "Assessment of Vulnerability of Coastal Cultural and Archaeological Resources to Sea-Level Rise and Coastal Processes: Gulf Islands National Seashore Florida and Mississippi, Recommendations for Protection and Preservation." 2003GUIS. Geoscientists-in-the-Parks. Fort Collins, Colorado: National Park Service.

Toulmin, S.E. 2003. The Uses of Argument. New York City, New York: Cambridge University Press.

United States Congress. 1916. Organic Act. 16 U.S.C. 1. Vol. 39 Stat. 53.

WHC. 2006. "Predicting and Managing the Effects of Climate Change on World Heritage: A Joint Report from the World Heritage Centre, Its Advisory Bodies, and a Broad Group of Experts to the 30th Session of the World Heritage Committee." Vilnius, Lithuania: United Nations Educational, Scientific, and Cultural Organization. http://whc.unesco.org/en/climatechange/.

Yin, R.K. 2003. Case Study Research: Design and Methods. 3rd ed. Thousand Oaks, California: Sage Publications. 
[Appendix A] 